\title{
Macroeconomic effects of household debt: an empirical analysis
}

\author{
Yun K. Kim* \\ Department of Economics, University of Massachusetts Boston, MA, USA
}

Multi-equation econometric frameworks are used to investigate the impact of household debt on GDP in the US. In the vector autoregression analysis capturing the transitory feedback effects, we observe a bidirectional positive feedback process between aggregate income and debt. According to the estimation of vector error correction models, there are negative long-run relationships between household debt and output. These empirical results provide a support for the view of the debt-driven business cycles.

Keywords: household debt, business cycles, financial instability hypothesis, cointegration, VAR, VECM

JEL codes: $C 32, E 21, E 32$

\section{INTRODUCTION}

Prior to the financial crisis of 2007, the US experienced a significant increase in household debt relative to income. Figure 1 depicts the ratios of consumer, mortgage, and household debt (sum of mortgage and consumer debt) relative to gross domestic product (GDP). Household debt outstanding as a share of GDP, for example, increased from about 45 percent in 1975 to nearly 100 percent in 2009. Although there is more fluctuation in the consumer debt-GDP ratio, a clear upward trend is observed, especially since 1985 . Mortgage debt seems to be a dominating component of household debt, and the household and mortgage debt-GDP ratios seem to show close comovements.

Figure 2 depicts the evolution of debt-net worth ratios. This provides additional evidence of the substantial increase in debt. Similar to the debt-GDP ratios, both household and mortgage debt-net worth ratios exhibit a clear upward trend over the whole sample period. Consumer debt-net worth ratio shows an upward trend until the middle of 1970, but, after that, it shows considerable fluctuations. In general, the liability side has grown more rapidly than the asset side over the sample period. Similar to the debt-GDP ratios, household and mortgage debt-net worth ratios seem to show close comovements.

* Email: Yun.Kim@umb.edu. I would like to thank Robert Blecker for his very helpful and detailed suggestions. Alan Isaac and Martha Starr also offered a number of helpful comments. Earlier versions of this paper were presented at a Trinity College political economy workshop and a UMass Amherst analytical political workshop, and I would like to thank the participants. Referees suggested a number of helpful and detailed points to improve the paper. All remaining errors are mine. 

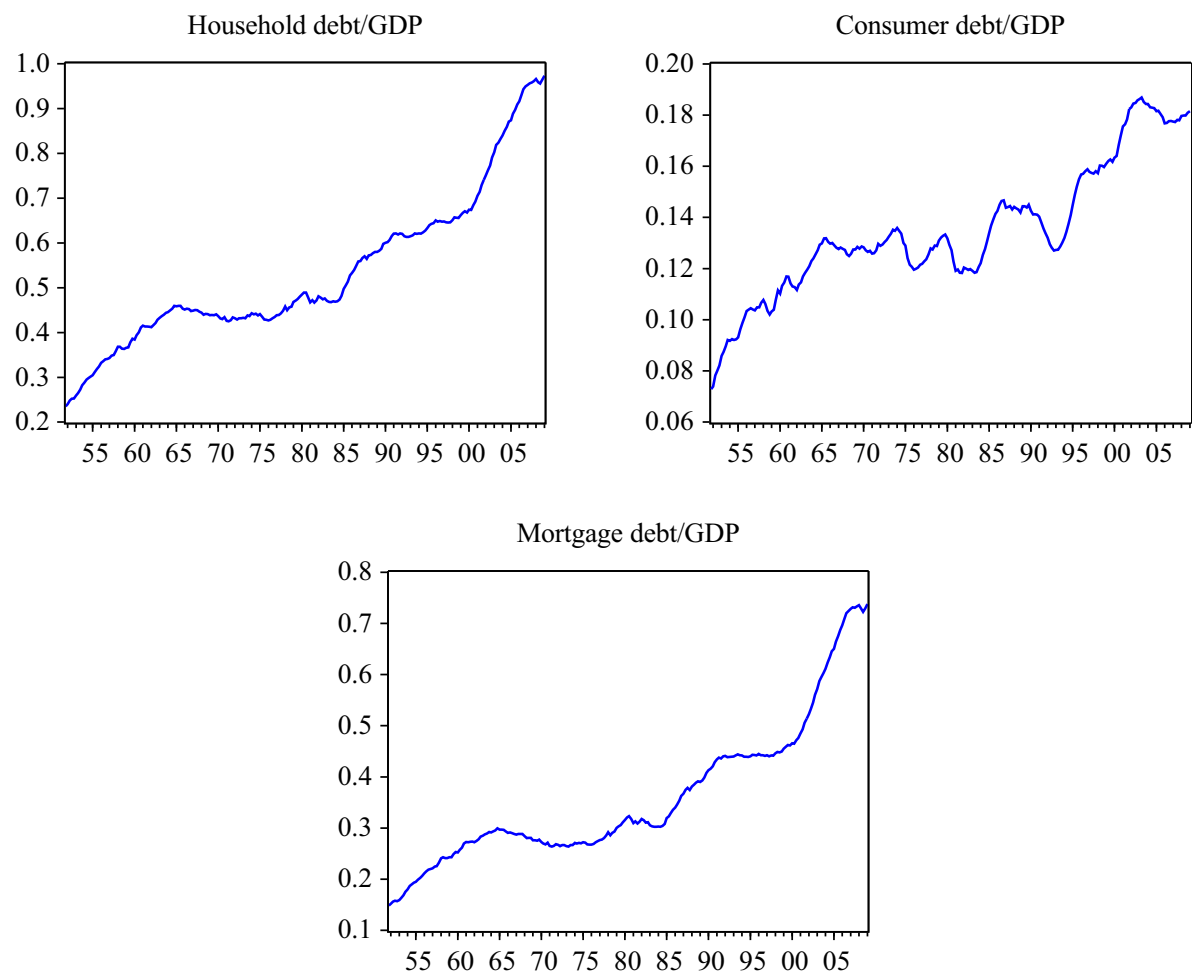

Figure 1 Debt outstanding as a share of GDP (1951Q4-2009Q1)

Figure 3 depicts two measures of the debt service burden: household financial obligations as a percentage of disposable personal income (FODSP) and household debt service payments as a percentage of disposable personal income (TDSP). These two series have been used by the Federal Reserve as primary measures of the household debt burden (Greenspan 2004), and are available starting in 1980. ${ }^{1}$ Both measures also show upward trends, indicating that households' financial positions have been continuously worsening. These levels of debt accumulation eventually proved untenable - as has been broadly implied in the Great Recession.

A number of post-Keynesian scholars have addressed the macroeconomic implications of household debt using formal models. For example, Palley (1994) incorporates consumer debt into a linear multiplier-accelerator model and analyses the cyclical aspects of consumer borrowing over the business cycle. In his model, a rise in consumer debt initially increases consumption and hence promotes growth, but eventually the accumulation of debt becomes excessive. This implies that there is a transfer of income from low saving agents (debtors) to high saving agents (rentiers) at an

1. The debt-service ratio measures the share of income committed by households for paying interest and principal on their debt. The financial obligations ratio, in addition to including debt payments, incorporates households' other recurring expenses - such as rents, auto leases, homeowners' insurance, and property taxes - that may be subtracted from the uncommitted income available to households (Greenspan 2004). 

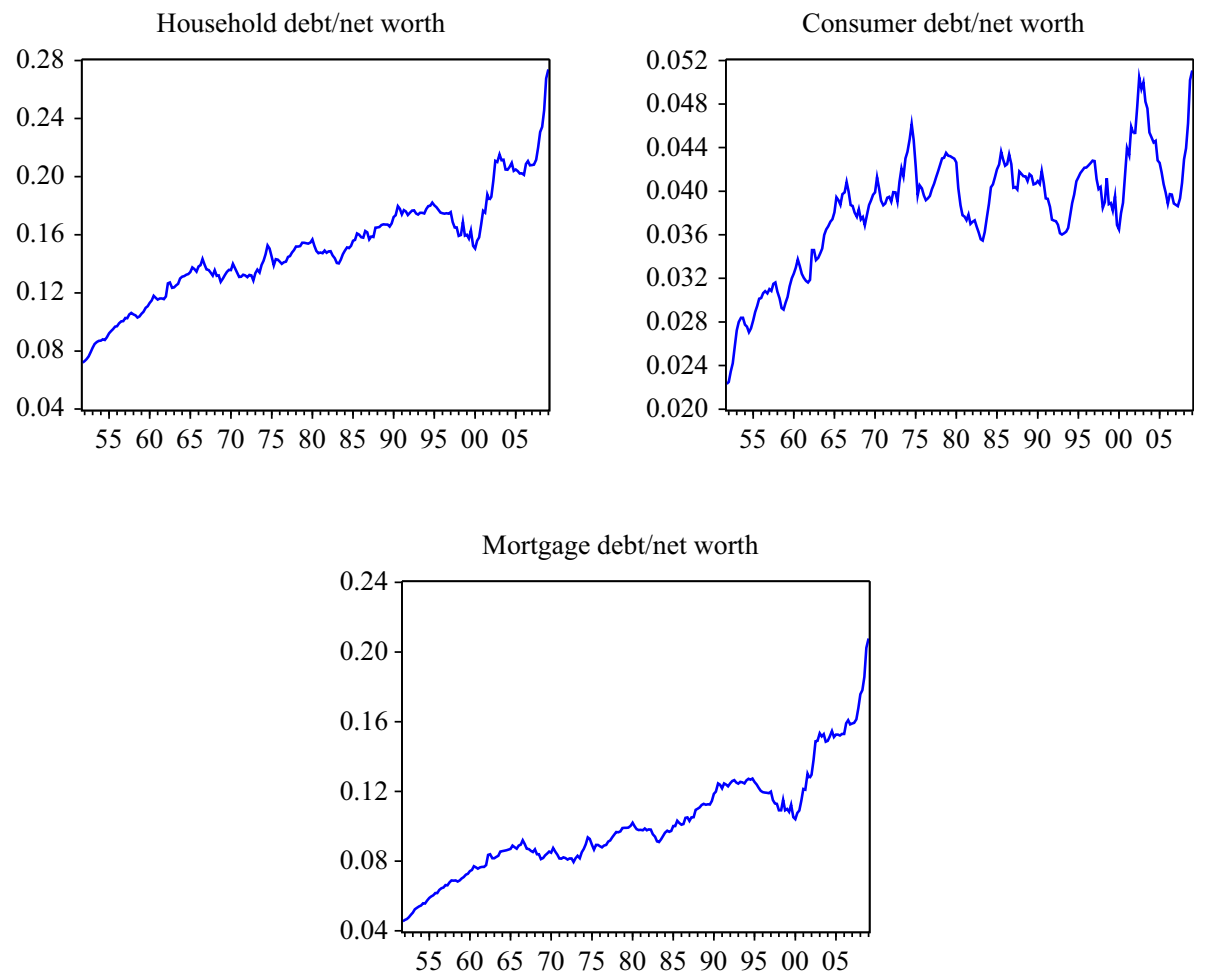

Figure 2 Debt outstanding as a share of household net worth (1951Q4-2009Q1)

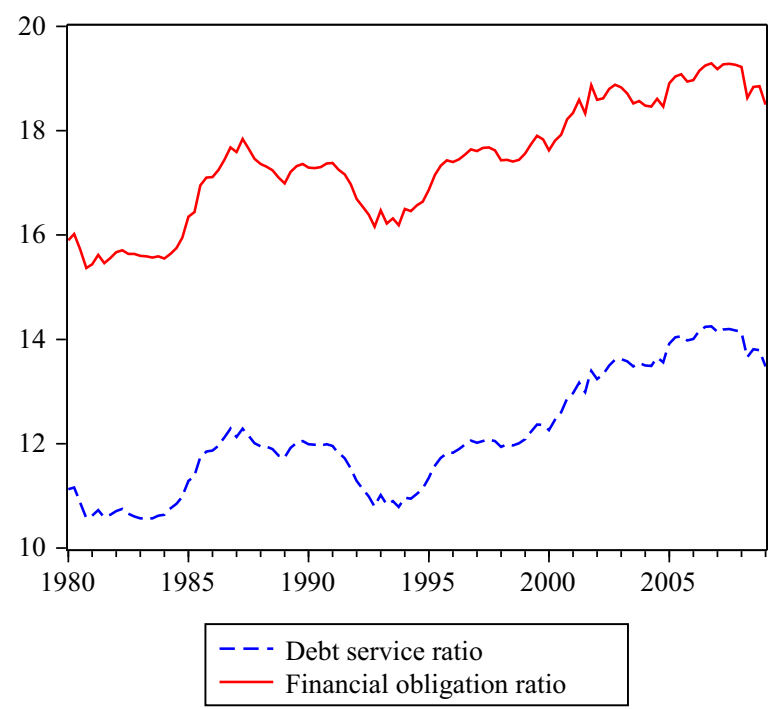

Figure 3 Debt service and financial obligation as a share of disposable income (1980Q1-2009Q1) 
increasing rate due to the debt service payments. The debt service burden then reduces consumption and output level. This provides a mechanism of credit-driven cyclical process of output. Dutt (2006) investigates the role of consumer debt within a neoKaleckian growth and distribution framework. In Dutt's model, an increase in household consumption debt raises the growth rate in the short run. In the long run, however, the effect is ambiguous because the accumulation of consumer debt results in a shift in income distribution toward rentiers, who have a higher propensity to save. This latter result has a depressing effect on the long-run growth rate in a demand-driven model. Nishi (2012) incorporates an endogenous interest rate into a neo-Kaleckian growth model, where the change in interest rate responds to workers' indebtedness, and investigates the dynamic stability of the system. He also demonstrates that the introduction of household borrowing can change the characteristics of a demand-generating process (that is, wage-led and profit-led). ${ }^{2}$

Post-Keynesian thoughts on the effect of debt on the macroeconomy are also strongly influenced by Hyman Minsky's financial instability hypothesis. Minsky's theory clarifies the two-sided aspects of debt-financed spending. During the boom phase of the business cycle, debt-financed household spending (and investment as traditionally emphasized) provides a source of additional economic stimulus. ${ }^{3}$ However, as the economy experiences a prolonged phase of prosperity, more debt-financed spending occurs and the debt-to-income ratio eventually rises. The balance sheets of businesses and households deteriorate and the system becomes financially fragile. The system becomes highly vulnerable to negative shocks, potentially resulting in a severe economic downturn.

Minsky's financial instability hypothesis has been applied to household debt by Cynamon and Fazzari (2008), who provide a very informative discussion of household debt from a Minskyan perspective. They observe that, from the 1980s to the early 2000s, the US experienced consumption expansion accompanied by significant household debt accumulation. Cynamon and Fazzari (2008) argue that, although this provided a substantial macroeconomic stimulus, this unprecedented rise in household debt could have planted the seeds for financial instability and a non-trivial economic downturn.

As the argument by Cynamon and Fazzari (2008) implies, Minsky's financial instability hypothesis can be read as highlighting distinctive debt effects depending on the time frame under consideration. Debt-financed household spending may provide a source of additional economic stimulus in the shorter time period, but eventually the accumulation of debt could become excessive, generating a negative impact on consumption and output level in the long run (for example through the higher debt service payments and frugal consumer behavior due to the excessive debt level). The system could become highly vulnerable to negative shocks, potentially resulting in a severe economic downturn. From this point of view, there are distinguishing effects of debt in the short and longer time period. ${ }^{4}$

2. See also Hein (2012), Isaac and Kim (2013), Kim et al. (2014), and Kapeller and Schütz (2015) for other neo-Kaleckian growth models with consumer debt.

3. Household debt played little role in Minsky's works, and most subsequent research also largely neglected household debt until the Great Recession.

4. In this respect, Minsky's financial instability hypothesis could be seen as a long wave theory. See Minsky (1964; 1995). Palley (2011) also distinguishes short cycles and super cycles in interpreting the financial instability hypothesis. Palley relates Minsky's financing taxonomy 
I approach my empirical investigation from the theoretical perspective of debt-driven business cycles. I will empirically distinguish the short-run and the long-run impact of household debt on real GDP. Multi-equation econometric frameworks are used to analyse the relationship between household debt and aggregate income. I study the unit roots and cointegrating relationships. Based on the findings, I implement vector autoregression (VAR) and vector error correction (VECM) models. In the VAR analysis, which captures the transitory (short-run) feedbacks among the growth rates of debt, GDP, and net worth, I observe a bidirectional positive feedback process between aggregate income and debt. According to the VECM estimation, which captures longrun relationships in a multi-equation framework, there is a negative long-run relationship between household debt and output. Our results provide evidence for household debt-driven business cycles.

\section{EMPIRICS}

\subsection{The three-variable system of debt, GDP, and net worth}

Appendix A1 presents detailed information about the data I use. Our data covers the period 1951Q4-2009Q1. ${ }^{5}$ I deflate the nominal data with the personal consumption chain-type price index from the national income and product accounts. I first examine the three-variable system of debt, GDP, and net worth. The main question of this study is the relationship between debt and GDP. One channel through which debt can influence GDP is the balance-sheet effect through the consumption function (Mishkin 1977; 1978). An increase in assets will have a positive effect on consumption and an increase in liabilities will depress consumption. Mishkin $(1977 ; 1978)$ distinguishes debt and financial assets in his estimation of the balance-sheet effect on consumption. I simply add a net worth variable to control for the effect from the asset side. In this paper, I consider all consumer, mortgage, and household debt to see whether a different composition of debt provides different results. Figures 4 and 5 present the graphs of the log levels and growth rates (first difference of logarithms) for these variables. I first investigate the stationarity properties of each series, as this is a necessary step for investigating cointegration between variables. Cointegration will be then investigated, and based on the results, an appropriate empirical model will be implemented to study the interrelationships between the variables.

\subsubsection{Unit root and cointegration tests}

In this section, the stationarity properties of the data are formally investigated. Two methods for the test are employed: the Augmented Dickey-Fuller (ADF) test and the Phillips-Perrorn (PP) test.

The tests for GDP, mortgage debt, and net worth indicate unit roots either with or without time trend in an estimation equation. Test results for household and consumer debt depend on the inclusion of time trend. Based on the procedure suggested by

(hedge, speculative, and ponzi) with short cycles that an economy goes through more frequently and financial crisis with super cycles that are associated with more fundamental structural changes.

5. The quarterly household financial data I use is available from the Federal Reserve flow of fund account starting from the fourth quarter of 1951. 
132 Review of Keynesian Economics, Vol. 4 No. 2
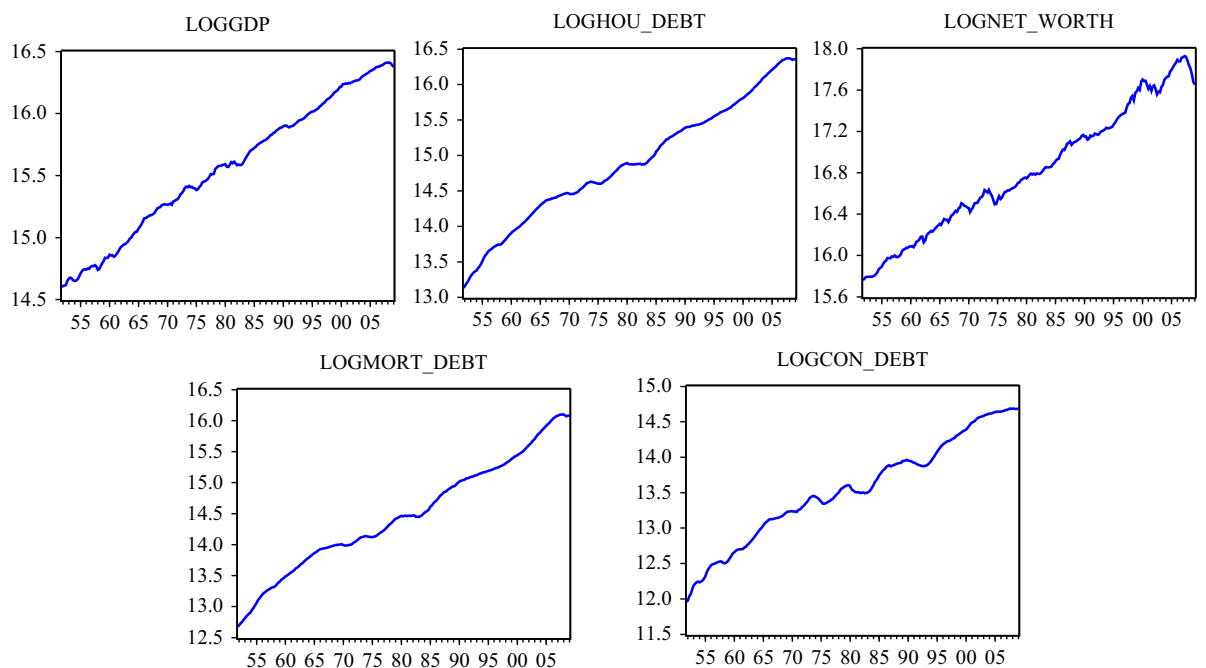

Figure 4 Variables in the logarithmic level
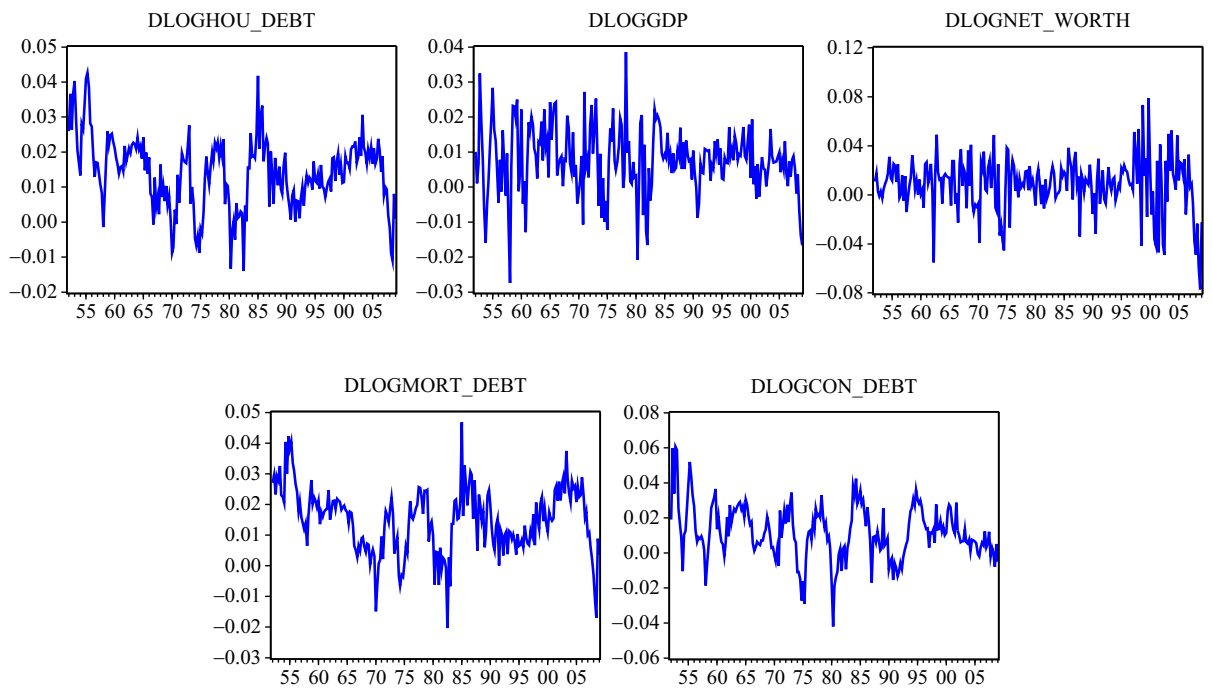

Figure 5 Log variables in first difference

Dolado et al. (1990) using F-statistics, ${ }^{6}$ I could conclude that a drift term, but not a linear time trend, should be included in the estimating equation. Without time trends, the tests indicate evidence for unit roots. PP tests provide the same results. Table 1

6. See also Enders (2004) for a discussion of the procedure. 
Table 1 Unit roots tests for log-transformed variables

\begin{tabular}{lcc}
\hline & PP & ADF \\
\hline Real GDP & -1.442 & -1.396 \\
& $(0.561)$ & $(0.584)$ \\
Household debt & -1.828 & -1.062 \\
& $(0.367)$ & $(0.731)$ \\
Net worth & -1.124 & -1.170 \\
& $(0.707)$ & $(0.688)$ \\
Consumer debt & -2.170 & -1.380 \\
& $(0.218)$ & $(0.592)$ \\
Mortgage debt & -1.239 & -0.840 \\
& $(0.657)$ & $(0.805)$
\end{tabular}

Notes: ADF and PP test statistics with $p$-values are reported. Lag lengths are selected by Schwarz Information Criteria (SIC). Drift term, but no time trend in the estimating equations. The null hypothesis is that the variable has a unit root. MacKinnon $(1991 ; 1996)$ one-sided critical values and $p$-values are used.

reports the results of both $\mathrm{ADF}$ and PP test results without linear time trends in the estimating equations. ${ }^{7}$ I conclude that all series are nonstationary.

Cointegration analysis reveals the long-run relationship between economic variables, if any exists. The variables are linearly cointegrated if they share a common stochastic trend and if they are linearly related to each other across the variables. A linear combination of the variables, therefore, should provide a stationary variable. The unit root test results indicate that the individual variables in the series have stochastic trends, which is a necessary but not sufficient condition for the existence of cointegration between them. I use the cointegration tests developed by Johansen (1988). His methodology is VAR-based and utilizes a maximum likelihood estimation method.

Cointegration test statistics differ depending on the specification of the data-generating process and cointegrating relations across the variables. As shown in Figure 4, it is reasonable to assume that all the data have linear time trends. It is also assumed that a cointegration vector contains a constant, but no linear trend, as there is no plausible argument for a linear trend in the cointegrating vectors for the set of variables in our study.

Without regard for the lag length specifications, ${ }^{8}$ the three-variable systems with either household or mortgage debt are not cointegrated. The cointegration test results of the three-variable system with consumer debt depend on the lag length specification. With either one or three lag lengths (in first differences), the system with consumer debt possesses one cointegrating relationship. With either two or four lag lengths (in first differences), the system with consumer debt possesses no cointegrating relations. Given that household debt includes consumer debt, it may not be reasonable that the system with consumer debt contains a long-run equilibrium if the system with household debt does not possess a long-run equilibrium. I proceed to the VAR analysis of firstdifferenced series (rather than VECM) with the conclusion of no cointegration.

7. The first-differenced series are also stationary according to both the ADF and PP tests. All series are therefore integrated of order 1 (I(1)).

8. The lag lengths are selected by information criteria in a vector autoregression of undifferenced data. 


\subsubsection{VAR analysis: short-run perspectives}

Because the series exhibit unit roots, I express them in first differences, which approximate the growth rates of variables. The lag lengths of the VARs are selected based on the majority of the information criteria. ${ }^{9}$ A constant is specified in the VAR estimations.

VAR allows us to examine the interaction of the variables via impulse responses. I show impulse response results in Figures 6, 7, and 8. The impulse response figures include two standard error bands constructed by Monte Carlo methods with 1000 repetitions as an indication of statistical significance. The reported figures are generalized impulse responses. The advantage of generalized impulse responses is that the results do not depend on the specific restriction of the error structures. The results show that positive household, consumer, mortgage debt growth rate shocks are associated with an increase in the growth rate of GDP, and a positive GDP growth rate shock is associated with an increase in the growth rate of debt. (These positive feedbacks are statistically significant for some periods as the two standard error bands indicate.) Therefore, we
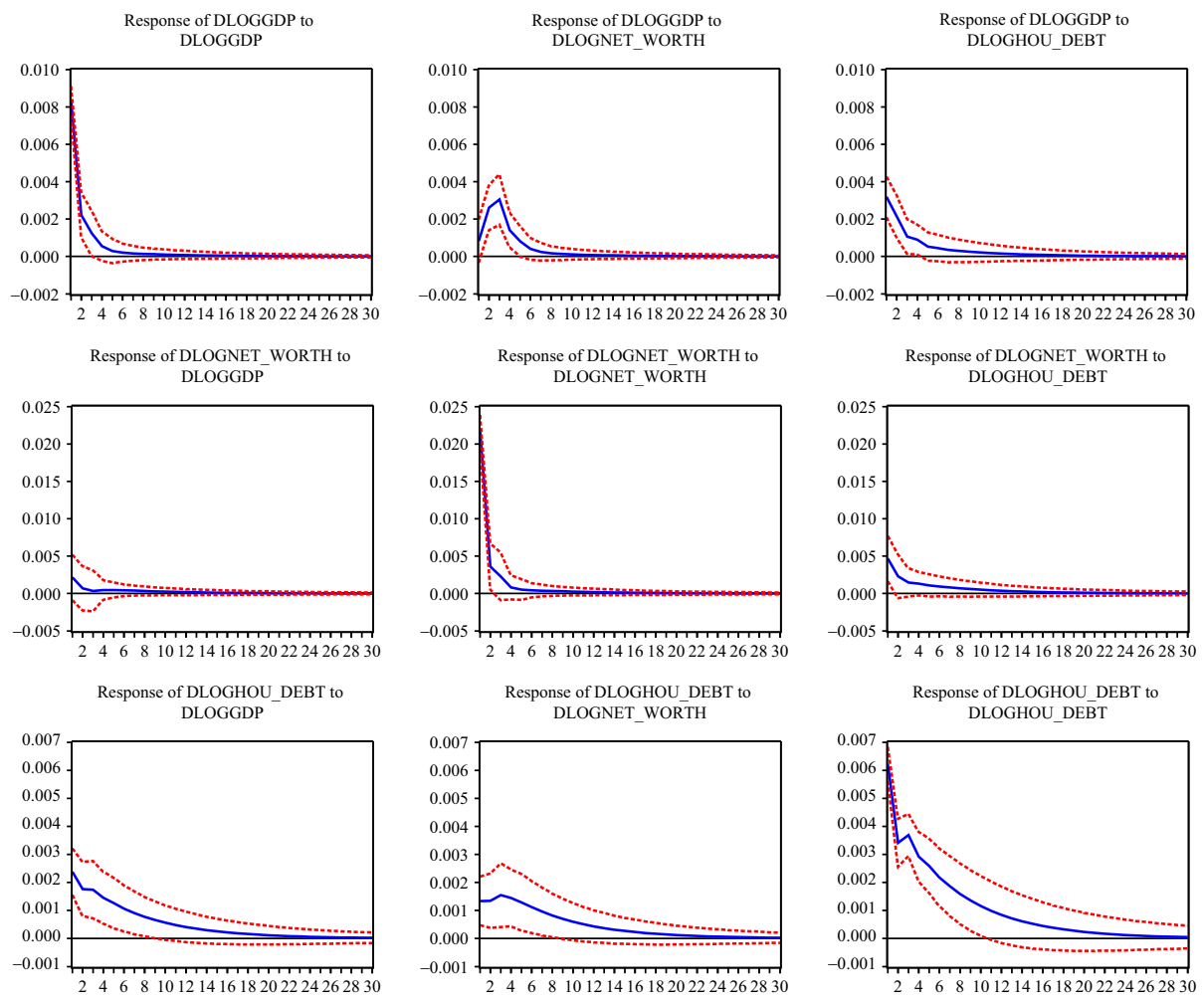

Figure 6 Generalized impulse responses of the growth rates of household debt, GDP and net worth

9. The information criteria I used for the lag length selection are: sequential modified LR test statistic, final prediction error, Akaike information criterion, Schwarz information criterion, and Hannan-Quinn information criterion. The results are available upon the request. 

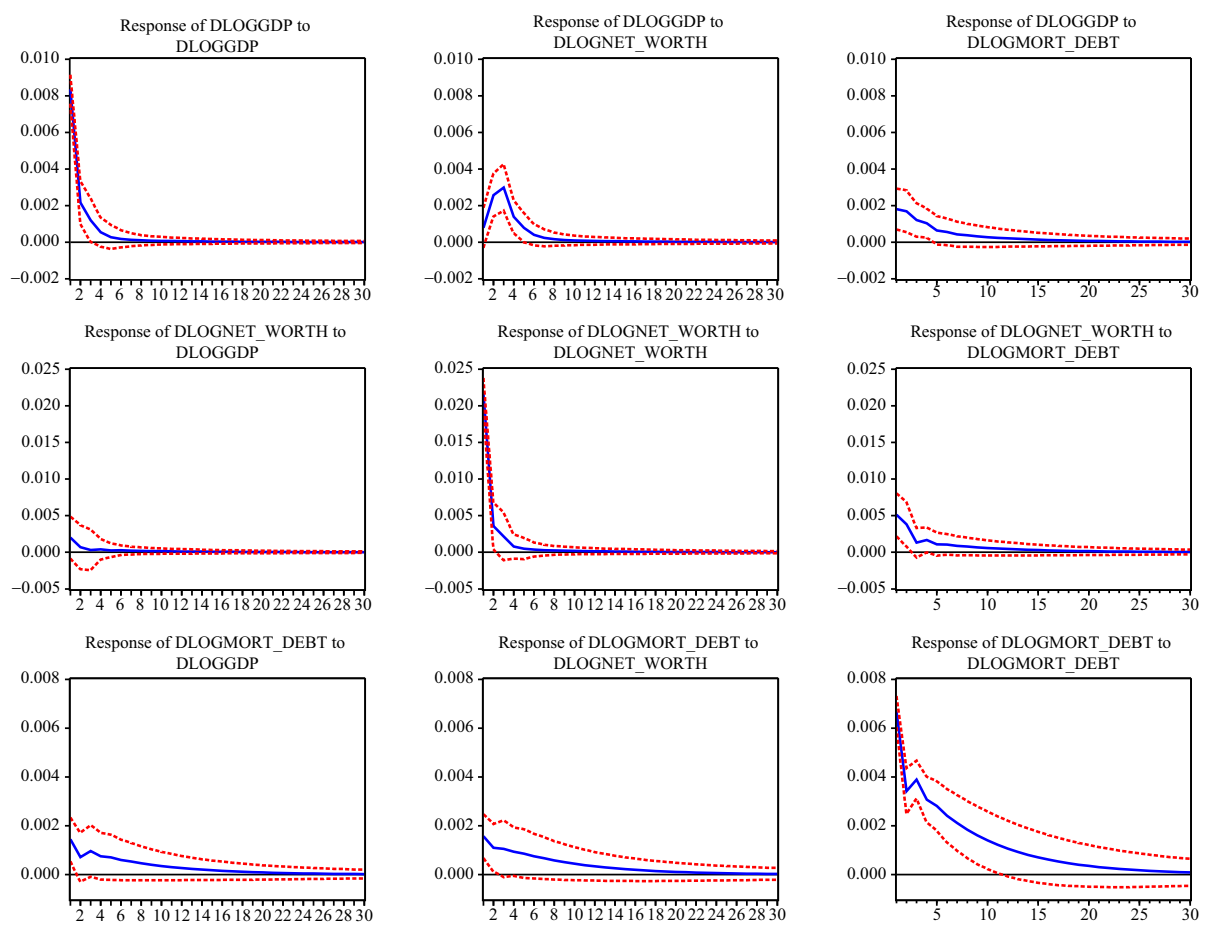

Figure 7 Generalized impulse responses of the growth rates of mortgage debt, GDP and net worth

observe a bidirectional positive feedback process between aggregate income and all debt measures. ${ }^{10}$

Note that, by using the first differenced variables, the shocks to variables only have temporary effects. Impulse responses in this case only capture transitory effects. The results show that household borrowing can provide an economic stimulus in the short run, providing supportive evidence for a credit-driven cyclical process of output, where household borrowing stimulates economic activity in the short run. It also provides positive evidence on one aspect of Minsky's financial instability hypothesis applied to household debt: in the transitory phase, we observe a bidirectional positive feedback process between aggregate income and debt accumulation.

\subsection{Cointegration and vector error correction models}

In the previous section, the evidence of cointegration was largely absent. One of the possible explanations might be the absence of a relevant variable, especially

10. I also performed impulse analyses of VAR with consumption as one of the main channels through which debt and net worth affect GDP is through consumption. The results with consumption are essentially identical to the results in the present section (2.1.2); we again observe a bidirectional positive feedback process between aggregate income and all debt measures. The impulse response results of the VAR with household debt are presented in Appendix A2. 
136 Review of Keynesian Economics, Vol. 4 No. 2
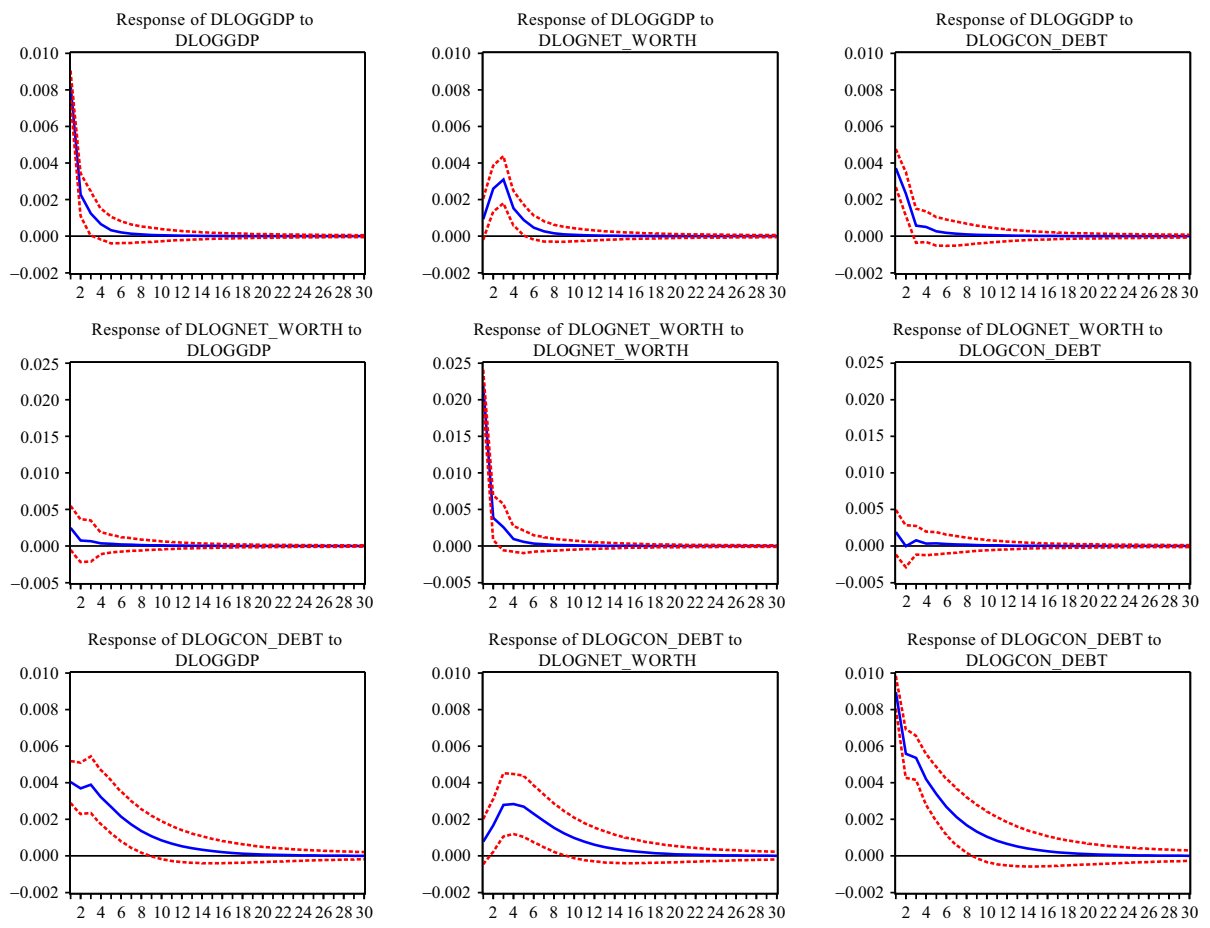

Figure 8 Generalized impulse responses of the growth rates of consumer debt, GDP and net worth

consumption, as consumption should be a main channel through which household debt and net worth should affect output. For this reason, I add consumption to the threevariable system of debt, net worth, and GDP, creating a four-variable system, and again using the three alternative measures of debt.

Cointegrating relationships between variables are again investigated via the Johansen test (Johansen 1988). The lag lengths for the estimating equations are selected by information criteria utilizing a vector autoregression of undifferenced data. ${ }^{11}$ It is reasonable to assume that all the data have a linear time trend (see Figures 4 and 9). ${ }^{12}$ I assume that the cointegration vector contains a constant, but not linear trend, as there is not a plausible argument for a linear trend in the cointegrating vectors for these four variables. Table 2 summarizes test results. (Mathematical notations are utilized to shorten the titles of tables. $Y, C, D$, and $N W$ denote GDP, consumption, debt, and net worth respectively. $D_{H}, D_{M}$, and $D_{C}$ denote household, mortgage, and consumer debt respectively.)

The results of cointegration tests for the system with household and mortgage debt depend on the lag lengths. For example, for the system with household debt, the trace test indicates one cointegrating relationship in the system with a two-lag specification. However, for the systems with either mortgage or household debt with seven lags, both

11. The lag length selection test results are available upon request.

12. Figure 9 shows the level and first-differenced real consumption expenditures. Both PP and $\mathrm{ADF}$ tests confirm that the log transformed real consumption is I(1) variable. 
LOG_CONSUMPTION

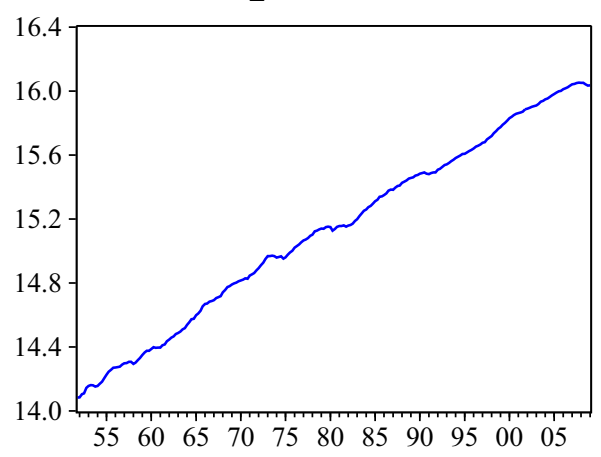

DLOG_CONSUMPTION

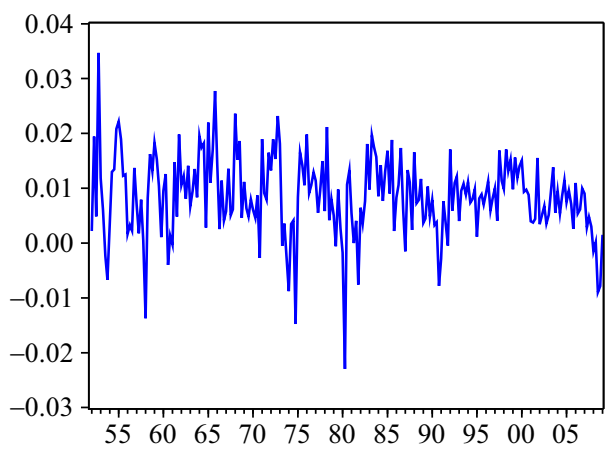

Figure 9 Log-transformed real personal consumption expenditure: level and firstdifferenced

Table 2 Cointegration rank tests: $\log \mathrm{Y}, \mathrm{D}, \mathrm{C}$, and $\mathrm{NW}$

\begin{tabular}{lcccc}
\hline $\begin{array}{l}\text { Debt type } \\
\text { Lag length }\end{array}$ & $\begin{array}{l}\text { Household }\left(D_{H}\right) \\
2 \text { lags }\end{array}$ & $\begin{array}{l}\text { Household }\left(D_{H}\right) \\
7 \text { lags }\end{array}$ & $\begin{array}{l}\text { Mortgage }\left(D_{M}\right) \\
7 \text { lags }\end{array}$ & $\begin{array}{l}\text { Consumer }\left(D_{C}\right) \\
3 \text { lags }\end{array}$ \\
\hline Trace & 1 & 2 & 2 & 1 \\
Max-Eig & 0 & 2 & 2 & 1 \\
\hline
\end{tabular}

Notes: Cointegration rank tests of the system of log-transformed GDP, debt, consumption, and net worth with different numbers of lags.

Significance level: 5 percent.

Critical values based on MacKinnon et al. (1999)

the trace and the max-eigenvalue (Max-Eig) tests indicate two cointegrating relationships. ${ }^{13}$ More detailed Johansen test results are presented in Tables A9, A10, A11, and A12 in Appendix A4.

The systems with one cointegrating relation are studied first. The VECM estimation results are presented in Tables A3 and A4 in Appendix A4. Equations (1) and (2) are the estimated long-run equilibrium relationships. Cointegrating vectors are normalized with respect to the GDP coefficient. All the coefficients in both equations (1) and (2) are significant at the 5 percent level, except for the coefficient for net worth in equation (2), which is significant at the 10 percent level. The signs of the coefficients are in accordance with the debt-driven cyclical process of output, where debt accumulation depresses economic activity in the long run. Both household debt and consumer debt have negative relationships with the level of output in the long run. (I also replace household net worth with household total assets and study the longrun relationships of the variables in Appendix A3. We find the same negative relationships. Furthermore, the additional results show that mortgage debt also has a negative relationship with output in the long run, even when a single cointegration case is considered.)

13. With lag lengths suggested by some information criteria, neither the trace nor the maxeigenvalue tests indicates the existence of cointegrating relations in the system. 


$$
\begin{aligned}
& G D P=0.763+0.948 \text { Consumption }+0.104 \text { NetWorth }-0.087 \text { Household Debt } \\
& G D P=0.926+1.267 \text { Consumption }+0.180 \text { NetWorth }-0.422 \text { Consumer Debt }
\end{aligned}
$$

Tables A3 and A4 in Appendix A4 also show the adjustment coefficients. Note that adjustment coefficients measure the feedback effects of disequilibrium onto the variables in the VECM. For the system with household debt, the adjustment coefficients of consumption and net worth indicate that these variables do not adjust significantly to shortrun deviations from the equilibrium. For the system with consumer debt, the adjustment coefficients of all variables, except consumer debt, do not adjust significantly to shortrun deviations from the equilibrium. This suggests the possibility of weak exogeneity of these variables to the parameters of interest. Weak exogeneity of the endogenous variables means that disequilibrium in the cointegrating relationship does not feed back onto these variables themselves. Estimators of and inference on the other parameter values (for example cointegrating vector), conditional on these weakly exogenous variables, do not suffer from a loss of information. Tables A5 and A6 in Appendix A4 report the estimation of the VECM with the restriction of weak exogeneity on these variables.

The results assuming weak exogeneity (Tables A5 and A6 in Appendix A4) can be contrasted with the results without the imposition of weak exogeneity (Tables A3 and A4 in Appendix A4). First of all, the restrictions could not be rejected according to the likelihood ratio tests (reported in Tables A5 and A6). For the system with household debt, the signs of the long-run coefficients are preserved, but the cointegrating coefficients for net worth and household debt are no longer significant (see equation (3)). ${ }^{14}$ For the system with consumer debt, the signs of the long-run coefficients are preserved, but the cointegrating coefficient for net worth is no longer significant (see equation (4)).

$$
\begin{gathered}
G D P=1.005+0.976 \text { Consumption } \\
G D P=1.079+1.331 \text { Consumption }-0.459 \text { Consumer Debt }
\end{gathered}
$$

As shown in Table A5 of Appendix A4, the growth rate of household debt adjusts negatively to disequilibrium, as indicated by the negative adjustment coefficients of the variable's equation. However, the short-run dynamic adjustment parameters (parameters of lagged differences) of household debt are also insignificant in all equations except its own. ${ }^{15}$ Household debt not only does not have any long-run relationships with consumption, GDP, and net worth, but also may not have any impact on them in the short run according to this result. According to the estimated long-run relationship, consumer debt has a negative relationship with GDP (equation (4)). In the short run, as shown in Table A6 of Appendix A4, the growth rate of consumer debt adjusts negatively to disequilibrium as the negative adjustment coefficients of the equation for this variable indicates. The direct impact of the growth rate of consumer debt on the other variables is mixed, as the short-run (lagged) dynamic adjustment parameters of the growth rate of consumer debt have mixed signs. The growth rate of consumer debt

14. A further restriction of the cointegrating coefficient for net worth being zero does not change the result for household debt; the cointegrating coefficient for household debt is still insignificant.

15. Owing to limited space, the estimates of short-run adjustment parameters from VECM estimations are omitted from the text. They are available upon request. I also emphasize that the main purpose of VECM estimations in this paper is to obtain long-run cointegrating relationships. 
has a positive impact on the growth rate of GDP with the first lag, but a negative impact with the third lag. On the other hand, the growth rate of consumer debt has a negative effect on the growth rate of consumption with the third lag, but no positive effect within the shorter lags (the coefficients for them are not significant).

\subsection{Multiple cointegrating vectors}

As Table 2 indicates, with seven lag lengths (suggested by likelihood ratio tests), the systems with household and mortgage debt have two cointegrating vectors in the characterization of the long-run equilibrium. In this section, I investigate these cases.

Multiple cointegrating relationships bring an additional complication. They require identification restrictions on each cointegration vector, so that each can be distinguishable from the others. Economic theory could provide such restrictions. In a conventional consumption function, household debt is not a separate argument since it is already accounted for in the net worth term. For this reason, I will identify each cointegrating vector by excluding the net worth term in the first cointegrating vector and the debt term in the second cointegrating vector. This provides sufficient binding restrictions for identification of long-run relations. The estimation results of the VECM with additional weak exogeneity restrictions are reported in Tables A7 and A8 in Appendix A4. ${ }^{16}$

$$
\begin{gathered}
G D P=1.351+0.941 \text { Consumption }-0.002 \text { Household Debt } \\
G D P=0.948+1.006 \text { Consumption }-0.043 \text { Mortgage Debt }
\end{gathered}
$$

Both household and mortgage debt terms have negative coefficients. A higher level of debt is associated negatively with GDP in the long run. (I also replace net worth with household total assets and study multiple cointegrating relationships of the variables in Appendix A3. I again find that both household and mortgage debt have negative relationships with output in the long run.) My results are in accordance with debt-driven cyclical process of output. I observe that debt accumulation depresses economic activity in the long run.

These results also provide some affirmative evidence on the long-run view of Minsky's financial instability hypothesis applied to household debt as they show that debt accumulation has a negative effect on output. However, I caution that Minsky's financial instability hypothesis is related more to the long-run instability and our work does not provide a direct evidence on such instability. I also note that the financial instability hypothesis is a complex process that requires more comprehensive and broad studies in addition to econometric investigations. ${ }^{17}$

According to the second cointegrating relations presented in Tables A7 and A8, net worth also has a negative relationship with GDP, which is in contrast to the conventional

16. I initially estimated a VECM without weak exogeneity restrictions. The long-run restrictions were not binding, and some of the adjustment coefficients were not significant. After imposing additional weak exogeneity restrictions on these insignificant adjustment coefficients, joint tests of long-run and weak exogeneity restrictions could not be rejected at the 5 percent significance level.

17. In terms of econometric studies, one should also look at the rise in the debt-income and debt-obligation ratios, and their impacts on macroeconomic stability to provide more evidence on the long-run aspect of Minsky's financial instability hypothesis applied to household debt. This is left for future research. 
positive wealth effect. ${ }^{18}$ The growth rates of household and mortgage debt adjust negatively to the first disequilibrium and positively to the second disequilibrium, as the adjustment coefficients of each variable's equations indicate (see Tables A7 and A8). However, the short-run dynamic adjustment parameters (parameters of lagged differences) of household and mortgage debt are mostly insignificant. In other words, according to these parameters, we do not see a significant short-run effect of household borrowing on the growth of output. Only the sixth short-run dynamic adjustment parameter of household debt in the GDP equation exhibits a positive impact of the growth rate of debt on the growth rate of GDP. The growth rate of household debt has a negative impact on the growth rate of consumption according to the fifth and seventh short-run dynamic adjustment parameters, but a positive impact according to the sixth short-run dynamic adjustment parameter in the consumption equation. None of the dynamic adjustment parameters of mortgage debt in the GDP equation is significant. Only the first dynamic adjustment parameters of household debt in consumption and net worth equations are significant and positive.

\section{DISCUSSION AND CONCLUSION}

A key theoretical perspective of this study is that household debt should have twosided effects, which provide the mechanism for debt-driven business cycles. Debtfinanced household spending may provide a source of additional economic stimulus in the shorter period, but eventually the accumulation of debt could become excessive, generating a negative impact on output in the long run. The system could become highly vulnerable to negative shocks, possibly resulting in a severe economic downturn. The effect of debt thus varies between shorter and longer time periods.

I investigated the relationship between household debt and aggregate income in the US from this perspective. In the VAR analysis, which captures the transitory feedbacks among the growth rates of debt, GDP, and net worth, I observed a bidirectional positive feedback process between aggregate income and debt. (I also performed the impulse analyses of VAR with consumption and found the same results as reported in Appendix A2.) This is in accordance with the short-run perspective of debt-driven business cycles. ${ }^{19}$ To distinguish between the short-run and long-run effect of household debt on output, I first investigated cointegrating relations between debt, GDP, net worth, and consumption via Johansen tests. Based on these tests, I estimated VECMs, which explicitly distinguish between the long-run relationships of the endogenous variables via cointegration and the short-run dynamics via adjustment parameters. (I also replaced net worth with assets and estimated cointegrating relationships, which are reported in Appendix A3.) According to the VECM estimation, there is a negative long-run relationship between debt and output as shown in equations (1), (2), (4), (5), and (6). ${ }^{20}$ (See also equations (A1),

18. I note that, for both the systems, about 120 parameters are estimated. This is more than half of the sample points. There is a rather dramatic reduction in the degrees of freedom. We therefore need to be cautious when interpreting these results.

19. However, in VECM estimations, many of the short-run adjustment parameters capturing the short-run impact of household borrowing on the growth of output are insignificant, and this indicates that my results from VAR analyses may not be robust.

20. I note that, for a single cointegration case, the negative relationship between output and household debt ceases to exist when the possibility of weak exogeneity is considered (see equation (3)). 
(A2), (A3), (A4), and (A5) in Appendix A3.) This is supportive evidence for the long-run perspective of debt-driven business cycles.

Our results also provide positive evidence to Minsky's financial instability hypothesis applied to US household debt. However, this interpretation requires a caution. Minsky's financial instability hypothesis is more concerned with macroeconomic instability and cannot be easily summarized by the simple statement that 'debt has positive effects in the short run, but negative effects in the long run.' In reality, an explosion of household debt may not result in a financial crisis and recession. There are other factors that may work to contain the effect of household debt explosion (for example, central bank monetary policy or financial sector regulation). Therefore, data do not necessarily predict the potentially disastrous effect of household debt. However, the recent Great Recession confirms the possibility of a financial crisis resulting from unsustainable accumulation of household debt.

\section{REFERENCES}

Cynamon, Barry Z. and Steven M. Fazzari (2008). 'Household debt in the consumer age: source of growth - risk of collapse.' Capitalism and Society, 3(2), Article 3.

Dolado, Juan, Tim Jenkinson, and Simon Sosvilla-Rivero (1990). 'Cointegration and unit roots.' Journal of Economic Surveys, 4(3), 249-273.

Dutt, Amitava K. (2006). 'Maturity, stagnation and consumer debt: a Steindlian approach.' Metroeconomica, 57(3), 339-364.

Enders, Walter (2004). Applied Econometric Time Series (2nd edn). Wiley Series in Probability and Statistics. Hoboken, NJ: Wiley.

Greenspan, Alan (2004). 'Understanding household debt obligations.' Remark made at the Credit Union National Association 2004 Governmental Affairs Conference, Washington, DC, February.

Hein, Eckhard (2012). 'Finance-dominated capitalism, re-distribution, household debt and financial fragility in a Kaleckian distribution and growth model.' PSL Quarterly Review, 65(260), 11-51.

Isaac, Alan G. and Yun K. Kim (2013). 'Consumer and corporate debt: a neo-Kaleckian synthesis.' Metroeconomica, 64(2), 244-271.

Johansen, Søren (1988). 'Statistical analysis of cointegration vectors.' Journal of Economic Dynamics and Control, 12(2-3), 231-254.

Kapeller, Jakob and Bernhard Schütz (2015). 'Conspicuous consumption, inequality and debt: the nature of consumption-driven profit-led regimes.' Metroeconomica, 66(1), 51-70.

Kim, Yun K., Mark Setterfield, and Yuan Mei (2014). 'A theory of aggregate consumption.' European Journal of Economics and Economic Policies: Intervention, 11(1), 31-49.

MacKinnon, James G. (1991). 'Critical values for cointegration tests.' In R.F. Engle and C.W.J. Granger, eds., Long-run Economic Relationships: Readings in Cointegration. Oxford: Oxford University Press.

MacKinnon, James G. (1996). 'Numerical distribution functions for unit root and cointegration tests.' Journal of Applied Econometrics, 11(6), 601-618.

MacKinnon, James G., Alfred A. Haug, and Leo Michelis (1999). 'Numerical distribution functions of likelihood ratio tests for cointegration.' Journal of Applied Econometrics, 14, 563-577.

Minsky, Hyman P. (1964). 'Longer waves in financial relations: financial factors in the more severe depressions.' The American Economic Review, 54(3), 324-335.

Minsky, Hyman P. (1995). 'Longer waves in financial relations: financial factors in the more severe depressions II.' Journal of Economic Issues, 29(1), 83-96.

Mishkin, Frederic S. (1977). 'What depressed the consumer? The household balance sheet and the 1973-75 recession.' Brookings Papers on Economic Activity, 1977(1), 123-174.

Mishkin, Frederic S. (1978). 'The household balance sheet and the great depression.' The Journal of Economic History, 38(4), 918-937.

Nishi, Hiroshi (2012). 'Household debt, dynamic stability, and change in demand creation patterns.' Review of Political Economy, 24(4), 607-622. 
142 Review of Keynesian Economics, Vol. 4 No. 2

Palley, Thomas I. (1994). 'Debt, aggregate demand, and the business cycle: a model in the spirit of Kaldor and Minsky.' Journal of Post Keynesian Economics, 16(3), 371-390.

Palley, Thomas I. (2011). 'A theory of Minsky super-cycles and financial crises.' Contributions to Political Economy, 30(1), 31-46.

\section{APPENDIX A1 DATA SOURCES AND DEFINITIONS}

\begin{tabular}{ll}
\hline Variables & Source \\
\hline Real GDP & BEA \\
Real consumption & BEA \\
Chain-type price index for PCE & BEA \\
Consumer debt & FED Flow of Fund \\
Household debt & FED Flow of Fund \\
Mortgage debt & FED Flow of Fund \\
Household net worth & FED Flow of Fund \\
Household total assets & FED Flow of Fund \\
FODSP & FED Flow of Fund \\
TDSP & FED Flow of Fund \\
\hline
\end{tabular}

BEA: Bureau of Economic Analysis (http://www.bea.gov/).

FED Flow of Fund: Federal Reserve Board Flow of Fund (http://www.federalreserve.gov/ releases/z1/Current/data.htm).

PCE: personal consumption expenditures.

Consumer debt is households' and non-profit organizations' consumer credit liability from Federal Reserve statistical release Z.1, FED Flow of Funds. The identification number is Z1/Z1/LA153166000.Q for the seasonally adjusted series.

Household debt is households' and non-profit organizations' credit and equity market instruments liability from Federal Reserve statistical release Z.1, FED Flow of Funds. The identification number is Z1/Z1/LA154102005.Q for the seasonally adjusted series.

Mortgage debt is households' and non-profit organizations' home mortgages liability from Federal Reserve statistical release Z.1, FED Flow of Funds. The identification number is Z1/Z1/LA153165105.Q for the seasonally adjusted series.

Household net worth is households' and non-profit organizations' net worth (market value) from FED Flow of Funds (Federal Reserve statistical release Z.1: FL152090005.Q).

Total assets are households' and non-profit organizations' total assets from Federal Reserve statistical release Z.1, FED Flow of Funds. The identification number is Z1/Z1/FL152000005.Q.

FODSP is Household Financial Obligations as a percentage of Disposable Personal Income from FED Flow of Funds (FOR/FOR/DTFDpercentYPD.Q).

TDSP is household debt service payments as a percentage of disposable personal income from FED Flow of Funds (FOR/FOR/DTFpercentYPD.Q). 


\section{APPENDIX A2 IMPULSE ANALYSIS OF VAR WITH CONSUMPTION}

I also performed impulse analyses of VAR with consumption. The results are essentially identical to the results in Section 2.1.2. The analysis shows that positive household, consumer, and mortgage debt growth rate shocks are associated with an increase in the growth rate of GDP, and a positive GDP growth rate shock is associated with an increase in the growth rate of debt. In other words, we again observe a bidirectional positive feedback process between aggregate income and all the debt measures in these extended systems. Figure A1 presents impulse response results with household debt. The figure shows a qualitatively similar response of GDP and consumption when there is a shock to household debt. (We see similar results with mortgage and consumer debt as well.) This suggests that consumption should be an important channel through which debt influences output. Impulse response analyses with mortgage and consumer debt are available upon request.

\section{APPENDIX A3 COINTEGRATION RESULTS WITH HOUSEHOLD ASSETS}

In this appendix, I present the cointegration results of four-variable systems with household total assets instead of net worth. These additional results will provide further evidence for the results presented in the main text. The same procedures I discussed in Section 2.2 are performed here. ${ }^{21}$ In summary, our results with total assets are consistent with the results I obtained with net worth.

The results of the cointegration tests again depend on the lag lengths. For the systems with either household or mortgage debt, the trace test indicates one cointegrating relationship in the systems with two lags. The system with household debt, with one lag, has also one cointegrating relationship according to the trace test. For the systems with either mortgage or household debt with seven lags, both the trace and max-eigenvalue tests indicate two cointegrating relationships. For the system with consumer debt, both the trace and max eigenvalue tests indicate one cointegrating relationship when it is specified with three lags. ${ }^{22}$ Tables A1 and A2 summarize the results.

Single cointegrating cases are presented first. Equations (A1), (A2), and (A3) present cointegrating relationships. ${ }^{23}$ The coefficient for assets in equation (A3) is significant at the 10 percent level and all other coefficients in the equations are significant at the 5 percent level. These results show that, similar to the result in Section 2.2, there is a negative long-run relationship between GDP and debt.

$$
\begin{gathered}
G D P=0.625+0.949 \text { Consumption }+0.137 \text { Assets }-0.117 \text { Household Debt } \\
G D P=0.701+0.915 \text { Consumption }+0.133 \text { Assets }-0.085 \text { Mortgage Debt } \\
G D P=-0.869+1.265 \text { Consumption }+0.185 \text { Assets }-0.431 \text { Consumer Debt }
\end{gathered}
$$

21. Both PP and ADF tests confirm that the log transformed real total assets are I(1) variable.

22. The detailed test results are available upon request.

23. The reported cointegration equation with household debt is from the system with two lags. The cointegration equation from the system with one lag shows qualitatively the same result. 
144 Review of Keynesian Economics, Vol. 4 No. 2
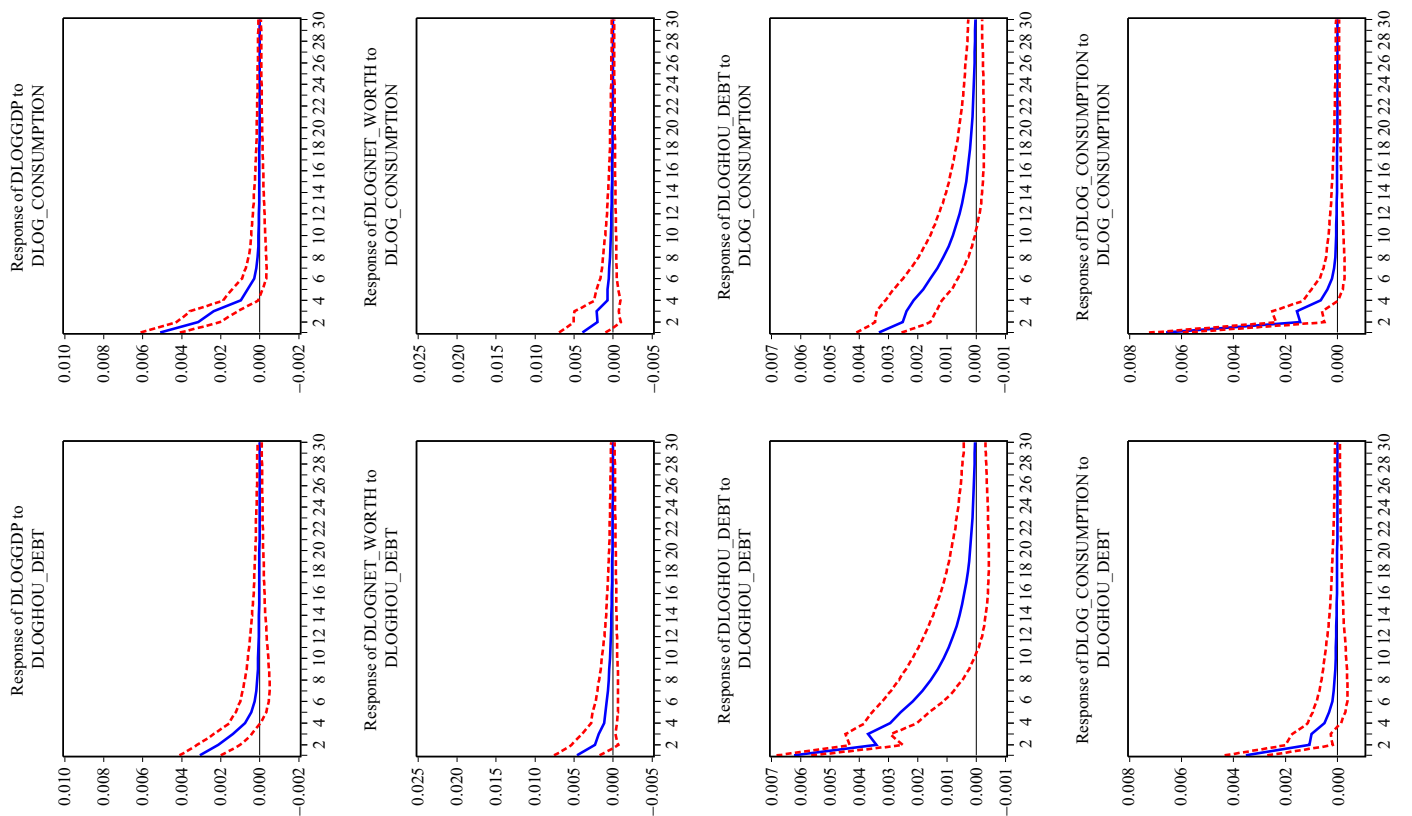

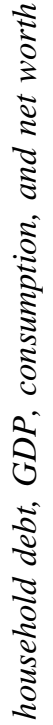
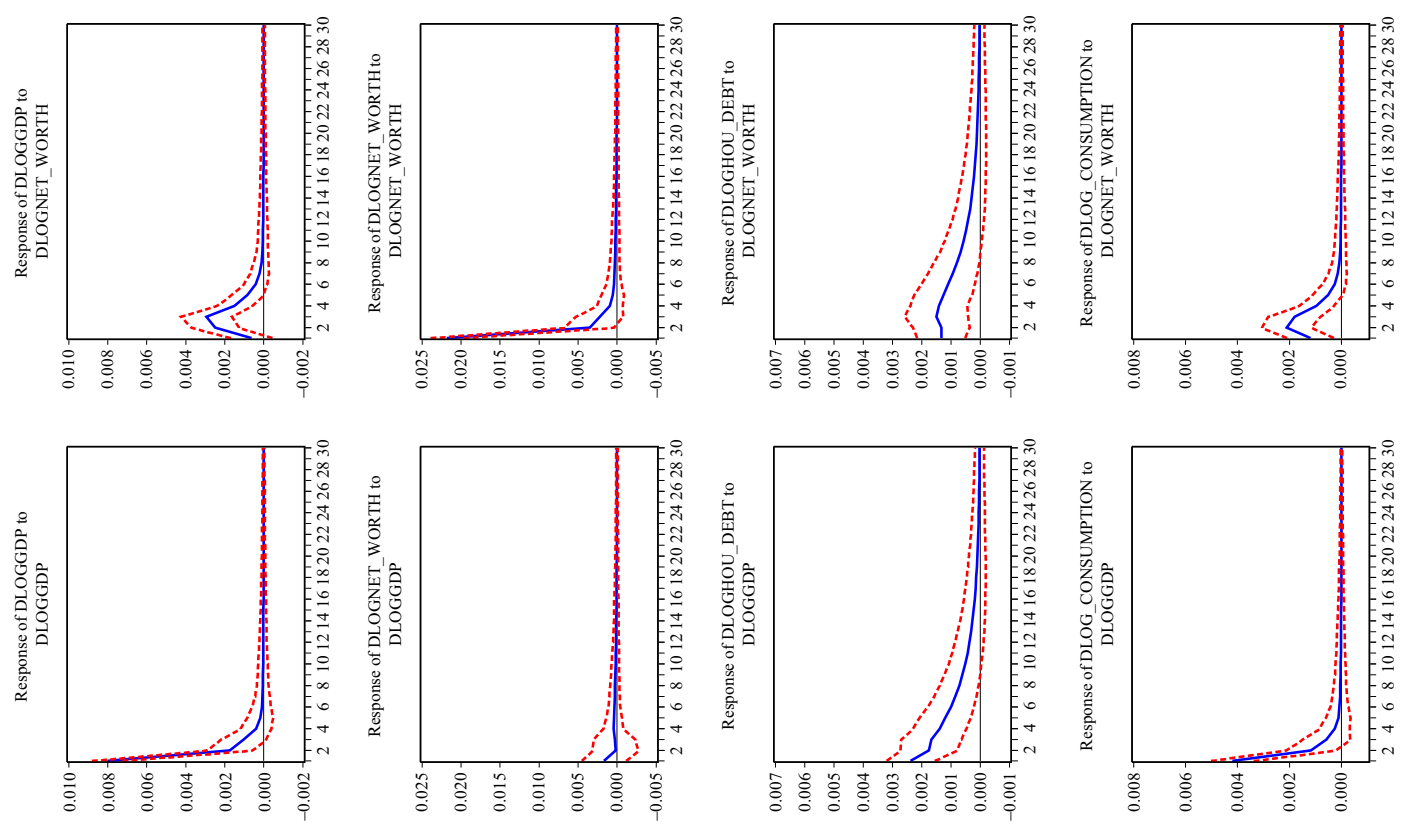

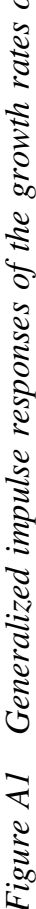


Table A1 Cointegration rank tests: $\log \mathrm{Y}, \mathrm{D}, \mathrm{C}$, and A

\begin{tabular}{|c|c|c|c|}
\hline $\begin{array}{l}\text { Debt type } \\
\text { Lag length }\end{array}$ & $\begin{array}{l}\text { Household }\left(D_{H}\right) \\
1 \text { lag }\end{array}$ & $\begin{array}{l}\text { Household }\left(D_{H}\right) \\
2 \text { lags }\end{array}$ & $\begin{array}{l}\text { Household }\left(D_{H}\right) \\
7 \text { lags }\end{array}$ \\
\hline Trace & 1 & 1 & 2 \\
\hline Max-Eig & 0 & 0 & 2 \\
\hline
\end{tabular}

Notes: Cointegration rank tests of the system of log-transformed GDP, debt, consumption, and assets (A) with different number of lags.

Significance level: 5 percent.

Critical values based on MacKinnon et al. (1999).

Table A2 Cointegration rank tests: $\log \mathrm{Y}, \mathrm{D}, \mathrm{C}$, and A

\begin{tabular}{lccc}
\hline $\begin{array}{l}\text { Debt type } \\
\text { Lag length }\end{array}$ & \multicolumn{2}{l}{$\begin{array}{l}\text { Mortgage }\left(D_{M}\right) \\
\text { 2 lags }\end{array}$} & $\begin{array}{l}\text { Consumer }\left(D_{C}\right) \\
\text { lags }\end{array}$ \\
\hline Trace & 1 & 2 & 3 lags \\
Max-Eig & 0 & 2 & 1 \\
\hline
\end{tabular}

Notes: Cointegration rank tests of the system of log-transformed GDP, debt, consumption, and assets with different number of lags.

Significance level: 5 percent

Critical values based on MacKinnon et al. (1999)

Equations (A4) and (A5) present the cointegrating relationships between debt and GDP from the multiple cointegration cases. I identify each cointegrating vector by excluding the assets term in the first cointegrating vector and the debt term in the second cointegrating vector. As in the main text, the reported cointegrating equations are from VECM estimations with additional weak exogeneity restrictions. ${ }^{24}$ All the coefficients in the equations are significant at the 5 percent level. Both household and mortgage debt terms have negative coefficients. A higher level of debt is associated negatively with GDP in the long run. These additional results in this appendix reinforce our results in Section 2.2. ${ }^{25}$

$$
\begin{aligned}
& G D P=1.082+0.991 \text { Consumption }-0.035 \text { Household Debt } \\
& G D P=0.920+1.011 \text { Consumption }-0.045 \text { Mortgage Debt }
\end{aligned}
$$

24. I initially estimated a VECM without weak exogeneity restrictions. The long-run restrictions were not binding, and some of the adjustment coefficients were not significant. After imposing additional weak exogeneity restrictions on these insignificant adjustment coefficients, joint tests of long-run and weak exogeneity restrictions could not be rejected at the 5 percent significance level.

25. Complete VECM results for this appendix are available upon request. 
146 Review of Keynesian Economics, Vol. 4 No. 2

\section{APPENDIX A4 TABLES}

Table A3 VECM estimation (2 lags): $\log \mathrm{Y}, \mathrm{D}_{\mathrm{H}}, \mathrm{C}$, and NW

\begin{tabular}{lcccc}
\hline Cointegrating Eq: & CointEq1 & & & \\
LOGGDP $_{-1}$ & 1 & & & \\
LOGCONSUMPTION $_{-1}$ & $-0.948^{*}$ & & & \\
& {$[-19.552]$} & & & \\
LOGHOUSEHOLDDEBT $_{-1}$ & $0.087^{* *}$ & & & \\
& {$[2.333]$} & & & \\
LOGNETWORTH $_{-1}$ & -0.104 & & & \\
C & {$\left[-2.058^{* *}\right]$} & & & \\
Error correction: & -0.763 & & & \\
CointEq1 & $\mathrm{D}(\mathrm{LOGGDP})$ & $\mathrm{D}(\mathrm{LOG}$ CON $)$ & $\mathrm{D}(\mathrm{LOG}$ & $\mathrm{D}(\mathrm{LOG}$ \\
& $-0.097^{* *}$ & -0.029 & HOU-DEBT $)$ & WORTH $)$ \\
& {$[-2.509]$} & {$[-0.906]$} & {$[-3.796]$} & {$[1.359]$} \\
\hline
\end{tabular}

Notes: VECM estimation of the system of log-transformed GDP, household debt, consumption, and net worth with two lags. The full estimation result including the short-run dynamic adjustment parameters are available upon request.

$*$, **, and *** denote significance at 10,5 , and 1 percent, respectively. $T$-statistics in parentheses.

Cointegrating vector normalized with respect to GDP coefficient.

Table A4 VECM estimation (3 lags): $\log \mathrm{Y}, \mathrm{D}_{\mathrm{C}}, \mathrm{C}$, and NW

\begin{tabular}{|c|c|c|c|c|}
\hline Cointegrating Eq: & CointEq1 & & & \\
\hline$L O G G D P_{-1}$ & 1 & & & \\
\hline LOGCONSUMPTION $_{-1}$ & $-1.267 *$ & & & \\
\hline & {$[-10.233]$} & & & \\
\hline$L_{O O G C O N S U M E R D E B T_{-1}}$ & $\begin{array}{r}0.422^{*} \\
{[4.965]}\end{array}$ & & & \\
\hline LOGNETWORTH $_{-1}$ & $\begin{array}{l}-0.181 * * * \\
{[-1.888]}\end{array}$ & & & \\
\hline$C$ & 0.926 & & & \\
\hline Error correction: & D(LOGGDP) & $\begin{array}{l}\mathrm{D}(\mathrm{LOG} \\
\text { CONS) }\end{array}$ & $\mathrm{D}(\mathrm{LOGCON}-\mathrm{DEBT})$ & $\begin{array}{c}\text { D(LOG } \\
\text { WORTH) }\end{array}$ \\
\hline CointEq1 & $\begin{array}{c}-0.002 \\
{[-0.114]}\end{array}$ & $\begin{array}{c}0.003 \\
{[0.192]}\end{array}$ & $\begin{array}{c}-0.074 * \\
{[-4.291]}\end{array}$ & $\begin{array}{c}0.034 \\
{[0.786]}\end{array}$ \\
\hline
\end{tabular}

Notes: VECM estimation of the system of log-transformed GDP, consumer debt, consumption, and net worth with three lags. The full estimation result including the short-run dynamic adjustment parameters are available upon request.

$*$, **, and *** denote significance at 10,5 , and 1 percent, respectively. $T$-statistics in parentheses.

Cointegrating vector normalized with respect to GDP coefficient. 


\section{Table A5 VECM estimation with restrictions (2 lags): $\log \mathrm{Y}, \mathrm{D}_{\mathrm{H}}, \mathrm{C}$, and $\mathrm{NW}$}

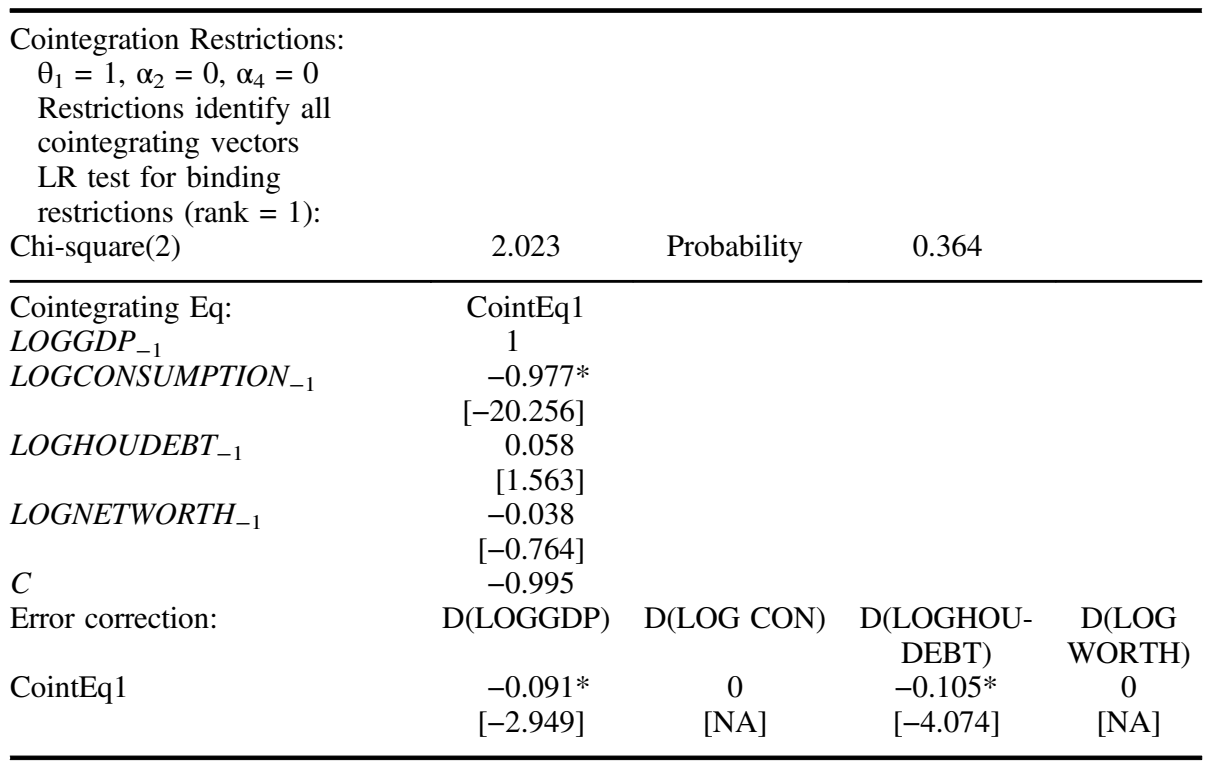

Notes: VECM estimation of the system of log-transformed GDP, household debt, consumption, and net worth with two lags (with restrictions on adjustment coefficients). The full estimation result including the short-run dynamic adjustment parameters are available upon request.

$*, * *$, and $* * *$ denote significance at 10,5 , and 1 percent, respectively. $T$-statistics in parentheses.

Cointegrating vector normalized with respect to GDP coefficient $\left(\theta_{1}=1\right), \alpha_{2}=0$ and $\alpha_{4}=0$ denote the restrictions on the adjustment (error correction) coefficients.

\section{Table A6 VECM estimation with restrictions (3 lags): $\log \mathrm{Y}, \mathrm{D}_{\mathrm{C}}, \mathrm{C}$, and $\mathrm{NW}$}

Cointegration Restrictions:

$\theta_{1}=1, \alpha_{1}=0, \alpha_{2}=0, \alpha_{4}=0$

Restrictions identify all

cointegrating vectors

LR test for binding

restrictions $($ rank $=1)$ :

Chi-square(3)

0.582 Probability

0.901

\begin{tabular}{|c|c|c|c|c|}
\hline Cointegrating Eq: & CointEq1 & & & \\
\hline$L O G G D P_{-1}$ & 1 & & & \\
\hline LOGCONSUMPTION $_{-1}$ & $\begin{array}{l}-1.331^{*} \\
{[-9.989]}\end{array}$ & & & \\
\hline$L O G C O N D E B T_{-1}$ & $\begin{array}{c}0.459^{*} \\
{[5.011]}\end{array}$ & & & \\
\hline LOGNETWORTH & $\begin{array}{c}-0.162 \\
{[-1.568]}\end{array}$ & & & \\
\hline C & 1.079 & & & \\
\hline Error correction: & $\begin{array}{c}\text { D } \\
\text { (LOGGDP) }\end{array}$ & $\begin{array}{l}\mathrm{D}(\mathrm{LOG} \\
\mathrm{CON})\end{array}$ & $\begin{array}{c}\text { D(LOGCON- } \\
\text { DEBT })\end{array}$ & $\begin{array}{c}\text { D(LOG } \\
\text { WORTH) }\end{array}$ \\
\hline CointEq1 & $\begin{array}{l}0 \\
{[\mathrm{NA}]}\end{array}$ & $\begin{array}{c}0 \\
{[\mathrm{NA}]}\end{array}$ & $\begin{array}{c}-0.071^{*} \\
{[-5.499]}\end{array}$ & $\begin{array}{c}0 \\
{[\mathrm{NA}]}\end{array}$ \\
\hline
\end{tabular}

Notes: VECM estimation of the system of log-transformed GDP, consumer debt, consumption, and net worth with three lags (with restrictions on adjustment coefficients). The full estimation result including the shortrun dynamic adjustment parameters are available upon request.

$*$, **, and *** denote significance at 10,5 , and 1 percent, respectively. $T$-statistics in parentheses.

Cointegrating vector normalized with respect to GDP coefficient $\left(\theta_{1}=1\right) . \alpha_{1}=0, \alpha_{2}=0$ and $\alpha_{4}=0$ denote

the restrictions on the adjustment (error correction) coefficientswnloaded from PubFactory at 04/26/2023 10:58:39AM 
148 Review of Keynesian Economics, Vol. 4 No. 2

Table A7 VECM estimation with restrictions (7 lags): $\log \mathrm{Y}, \mathrm{D}_{\mathrm{H}}, \mathrm{C}$, and NW

\begin{tabular}{|c|c|c|c|c|}
\hline $\begin{array}{l}\text { Cointegration Restrictions: } \\
\theta_{1,1}=1, \theta_{1,4}=0, \theta_{2,1}=1, \\
\theta_{2,3}=0, \alpha_{2,1}=0, \alpha_{2,2}=0 \\
\text { Chi-square(2) }\end{array}$ & 4.884 & Probability & 0.087 & \\
\hline$L O G G D P_{-1}$ & 1 & 1 & & \\
\hline$L_{O O G C O N S U M P T I O N}^{-1}$ & $\begin{array}{r}-0.941 * \\
{[-225.036]}\end{array}$ & $\begin{array}{r}-0.941^{*} \\
{[-224.245]}\end{array}$ & & \\
\hline LOGHOUDEBT $_{-1}$ & $\begin{array}{c}0.002 * \\
{[4.726]}\end{array}$ & 0 & & \\
\hline LOGNETWORTH $_{-1}$ & 0 & $\begin{array}{r}0.003 * \\
{[5.015]}\end{array}$ & & \\
\hline$C$ & -1.351 & -1.368 & & \\
\hline Error correction: & D(LOGGDP) & D(LOGCON $)$ & $\begin{array}{c}\text { D(LOGHOU- } \\
\text { DEBT })\end{array}$ & D(LOGWORTH) \\
\hline CointEq1 & $\begin{array}{l}6.061 * * * \\
{[1.883]}\end{array}$ & $\begin{array}{c}0 \\
{[\mathrm{NA}]}\end{array}$ & $\begin{array}{c}-9.203^{*} \\
{[-3.442]}\end{array}$ & $\begin{array}{l}29.219 * * \\
{[2.541]}\end{array}$ \\
\hline CointEq2 & $\begin{array}{l}-6.209 * * * \\
{[-1.933]}\end{array}$ & $\begin{array}{c}0 \\
{[\mathrm{NA}]}\end{array}$ & $\begin{array}{c}9.109 * \\
{[3.414]}\end{array}$ & $\begin{array}{c}-28.998 * * \\
{[-2.527]}\end{array}$ \\
\hline
\end{tabular}

Notes: VECM estimation of the system of log-transformed GDP, household debt, consumption, and net worth with seven lags (with restrictions on adjustment coefficients). The full estimation result including the short-run dynamic adjustment parameters are available upon request.

$*$, **, and *** denote significance at 10,5 , and 1 percent, respectively. $T$-statistics in parentheses.

Cointegrating vector normalized with respect to GDP coefficient $\left(\theta_{1,1}=1\right.$ and $\left.\theta_{2,1}=1\right) . \theta_{1,4}=0$ and $\theta_{2,3}=0$ denote identification restrictions on each cointegration vector. $\alpha_{2,1}=0$ and $\alpha_{2,3}=0$ denote the restrictions on the adjustment (error correction) coefficients.

Table A8 VECM estimation with restrictions (7 lags): $\log \mathrm{Y}, \mathrm{D}_{\mathrm{M}}, \mathrm{C}$, and $\mathrm{NW}$

\begin{tabular}{|c|c|c|c|c|}
\hline $\begin{array}{l}\text { Cointegration Restrictions: } \\
\begin{aligned} \theta_{1,1}=1, \theta_{1,4}=0, \\
\theta_{2,1}=1, \theta_{2,3}=0, \alpha_{2,2}=0 \\
\text { Chi-square }(2)\end{aligned}\end{array}$ & 1.473 & Probability & 0.225 & \\
\hline Cointegrating Eq: & CointEq1 & CointEq2 & & \\
\hline$L O G G D P_{-1}$ & 1 & 1 & & \\
\hline$L_{O O G C O N S U M P T I O N_{-1}}$ & $\begin{array}{c}-1.006^{*} \\
{[-73.355]}\end{array}$ & $\begin{array}{c}-1.026^{*} \\
{[-56.879]}\end{array}$ & & \\
\hline$L O G M O R T D E B T_{-1}$ & $\begin{array}{c}0.043 * \\
{[4.887]}\end{array}$ & 0 & & \\
\hline LOGNETWORTH $_{-1}$ & 0 & $\begin{array}{c}0.079 * \\
{[4.814]}\end{array}$ & & \\
\hline$C$ & -0.948 & -1.372 & & \\
\hline Error correction: & D(LOGGDP) & D(LOGCONS) & D(LOGMORTDEBT) & $\begin{array}{c}\text { D(LOG } \\
\text { WORTH) }\end{array}$ \\
\hline CointEq1 & $\begin{array}{l}0.306^{* *} \\
{[2.201]}\end{array}$ & $\begin{array}{c}0.086^{* *} \\
{[2.404]}\end{array}$ & $\begin{array}{c}-0.344 * * \\
{[-2.632]}\end{array}$ & $\begin{array}{c}1.363^{*} \\
{[2.888]}\end{array}$ \\
\hline CointEq2 & $\begin{array}{c}-0.344^{*} \\
{[-2.651]}\end{array}$ & $\begin{array}{l}0 \\
{[\mathrm{NA}]}\end{array}$ & $\begin{array}{c}0.281 * * \\
{[2.276]}\end{array}$ & $\begin{array}{l}-1.161^{* *} \\
{[-2.584]}\end{array}$ \\
\hline
\end{tabular}

Notes: VECM estimation of the system of log-transformed GDP, mortgage debt, consumption, and net worth with seven lags (with restrictions on adjustment coefficients). The full estimation result including the shortrun dynamic adjustment parameters are available upon request.

$*$, **, and $* * *$ denote significance at 10,5 , and 1 percent, respectively. $T$-statistics in parentheses.

Cointegrating vector normalized with respect to GDP coefficient $\left(\theta_{1,1}=1\right.$ and $\left.\theta_{2,1}=1\right) . \theta_{1,4}=0$ and $\theta_{2,3}=0$ denote identification restrictions on each cointegration vector. $\alpha_{2,2}=0$ denotes the restriction on the adjustment (error correction) coefficient. 
Table A9 Unrestricted cointegration test (2 lags): $\log \mathrm{Y}, \mathrm{D}_{\mathrm{H}}, \mathrm{C}$, and $\mathrm{NW}$

\begin{tabular}{lcccc}
\hline Hypothesized no of CE(s) & Eigenvalue & Trace statistic & 0.05 critical value & Prob. \\
\hline None* & 0.110 & 48.481 & 47.856 & 0.044 \\
At most 1 & 0.061 & 22.003 & 29.797 & 0.298 \\
At most 2 & 0.022 & 7.699 & 15.495 & 0.498 \\
At most 3 & 0.012 & 2.706 & 3.842 & 0.1 \\
\hline Hypothesized no of CE(s) & Eigenvalue & Max-Eigen statistic & 0.05 critical value & Prob. \\
\hline None & 0.110 & 26.479 & 27.584 & 0.069 \\
At most 1 & 0.061 & 14.304 & 21.132 & 0.341 \\
At most 2 & 0.022 & 4.993 & 14.265 & 0.743 \\
At most 3 & 0.012 & 2.707 & 3.842 & 0.1 \\
\hline
\end{tabular}

Notes: Unrestricted cointegration test of the system of log-transformed GDP, household debt, consumption, and net worth with two lags.

* Denotes rejection of the hypothesis at the 0.05 level.

MacKinnon et al. (1999) $p$-values reported.

Table A10 Unrestricted cointegration test (3 lags): $\log \mathrm{Y}, \mathrm{D}_{\mathrm{C}}, \mathrm{C}$, and $\mathrm{NW}$

\begin{tabular}{lcccc}
\hline Hypothesized no of CE(s) & Eigenvalue & Trace statistic & 0.05 critical value & Prob. \\
\hline None* & 0.127 & 53.457 & 47.856 & 0.014 \\
At most 1 & 0.052 & 22.796 & 29.797 & 0.256 \\
At most 2 & 0.032 & 10.645 & 15.495 & 0.234 \\
At most 3 & 0.015 & 3.398 & 3.842 & 0.065 \\
\hline Hypothesized no of CE(s) & Eigenvalue & Max-Eigen statistic & 0.05 critical value & Prob. \\
\hline None* & 0.127 & 30.661 & 27.584 & 0.019 \\
At most 1 & 0.052 & 12.150 & 21.132 & 0.533 \\
At most 2 & 0.032 & 7.248 & 14.265 & 0.460 \\
At most 3 & 0.015 & 3.398 & 3.842 & 0.065 \\
\hline
\end{tabular}

Notes: Unrestricted cointegration test of the system of log-transformed GDP, consumer debt, consumption, and net worth with three lags.

* Denotes rejection of the hypothesis at the 0.05 level.

MacKinnon et al. (1999) $p$-values reported.

Table A11 Unrestricted cointegration test (7 lags): $\log \mathrm{Y}, \mathrm{D}_{\mathrm{H}}, \mathrm{C}$, and $\mathrm{NW}$

\begin{tabular}{lccrc}
\hline Hypothesized no of CE(s) & Eigenvalue & Trace statistic & 0.05 critical value & Prob. \\
\hline None* & 0.149 & 72.575 & 47.856 & 0.0001 \\
At most 1* & 0.099 & 36.666 & 29.797 & 0.007 \\
At most 2 & 0.049 & 13.655 & 15.495 & 0.093 \\
At most 3 & 0.011 & 2.346 & 3.842 & 0.126 \\
\hline Hypothesized no of CE(s) & Eigenvalue & Max-Eigen statistic & 0.05 critical value & Prob. \\
\hline None* & 0.149 & 35.909 & 27.584 & 0.003 \\
At most 1* & 0.099 & 23.011 & 21.132 & 0.027 \\
At most 2 & 0.049 & 11.309 & 14.265 & 0.139 \\
At most 3 & 0.011 & 2.346 & 3.842 & 0.126 \\
\hline
\end{tabular}

Notes: Unrestricted cointegration test of the system of log-transformed GDP, household debt, consumption, and net worth with seven lags.

* Denotes rejection of the hypothesis at the 0.05 level.

MacKinnon et al. (1999) $p$-values reported. 
150 Review of Keynesian Economics, Vol. 4 No. 2

Table A12 Unrestricted cointegration test (7 lags): $\log \mathrm{Y}, \mathrm{D}_{\mathrm{M}}, \mathrm{C}$, and $\mathrm{NW}$

\begin{tabular}{lcccc}
\hline Hypothesized no of CE(s) & Eigenvalue & Trace statistic & 0.05 critical value & Prob. \\
\hline None* & 0.139 & 69.073 & 47.856 & 0.0002 \\
At most $1^{*}$ & 0.093 & 35.634 & 29.797 & 0.009 \\
At most 2 & 0.053 & 13.992 & 15.495 & 0.083 \\
At most 3 & 0.009 & 1.913 & 3.842 & 0.167 \\
\hline Hypothesized no of CE(s) & Eigenvalue & Max-Eigen statistic & 0.05 critical value & Prob. \\
\hline None* & 0.139 & 33.438 & 27.584 & 0.008 \\
At most 1* & 0.093 & 21.643 & 21.132 & 0.042 \\
At most 2 & 0.053 & 12.079 & 14.265 & 0.108 \\
At most 3 & 0.009 & 1.913 & 3.842 & 0.167 \\
\hline
\end{tabular}

Notes: Unrestricted cointegration test of the system of log-transformed GDP, mortgage debt, consumption, and net worth with seven lags.

* Denotes rejection of the hypothesis at the 0.05 level.

MacKinnon et al. (1999) $p$-values reported. 